\title{
Effects of bioactive substances in milk on mineral and trace element metabolism with special reference to casein phosphopeptides
}

\author{
Katharina E. Scholz-Ahrens* and J. Schrezenmeir \\ Department of Physiology and Biochemistry of Nutrition, Federal Dairy Research Centre, 24103 Kiel, Germany
}

\begin{abstract}
Bioactivity of phosphopeptides yielded after tryptic hydrolysis of casein (CPP) was reported more than 50 years ago when CPP were found to improve calcium balance in rachitic newborns. Several investigations have been carried out to study the effects of CPP mainly on calcium metabolism but also on other minerals like iron and zinc. Most of the experiments were in vitro studies or short-term experiments like the effects of CPP after single meals or their effect on mineral disappearance from intestinal everted sac or ligated loop. Investigations on calcium balance were also mainly short term, i.e. 3-4 weeks, and mainly done in rats. A few experiments have been carried out in minipigs, an animal model that is closer to the human than the rat. Studies in human were rare and short term. To date a variety of other peptides have been isolated after enzymatic hydrolysis, and some have been investigated for bioactivity, with equivocal findings. Bioactivity of phosphopeptides seemed to be more obvious when investigations were done in vitro or short term. Results were less clear in metabolic balance studies, especially under physiological conditions. The composition of the basal diet, i.e. content of calcium and phytate, or the protein source had a significant impact on the effect of phosphopeptides. It was concluded that phosphopeptides revealed positive effects on mineral solubility and absorbability, and bone mineralisation under certain experimental conditions. Accordingly they could have a beneficial effect on bone health for some groups of the population.
\end{abstract}

Phosphopeptides: Calcium absorption: Bone health

\section{Potential physiological action - short-term experiments Background}

Information on bioactive substances in milk which influence mineral metabolism is based on observations by Mellander (1947, 1950, 1963). Mellander (1950) incubated casein with pepsin and pancreatic juice. A fraction of peptides was yielded that were resistant to further degradation by proteolytic enzymes. The peptides were shown to contain phosphoserine-rich sequences and increase calcium balance by about 39-78 \% in rachitic newborns. Later, several authors demonstrated that phosphopeptides from tryptic digestion of casein (CPP) had a high affinity to calcium ions in vitro (Reeves \& Latour, 1958; Naito et al. 1972; Naito \& Suzuki, 1974). However, when calcium binding was studied in the presence of CPP using an Ussing chamber no effect was seen $(\mathrm{Li}$ et al. 1989).

\section{CPP liberation}

Naito and co-workers reported that CPP were liberated in vivo after feeding $\beta$-casein to rats (Naito et al. 1972; Naito \& Suzuki, 1974). It was found that liberation of CPP depended on digestion time of the meal. After feeding $200 \mathrm{~g}$ casein/ $/ \mathrm{kg}$ diet, liberation of CPP in the small intestine of rats occurred at 2.5 and $5.5 \mathrm{~h}$, but not at 13.5 and $25.5 \mathrm{~h}$ postprandially. The simultaneous feeding of casein and a basal diet proved to be necessary to release CPP in these experiments (Lee et al. 1980). Feeding casein alone (Lee et al. 1980), or the amino acid mixture equivalent to $200 \mathrm{~g}$ casein $/ \mathrm{kg}$ diet (Lee et al. 1983), did not have this effect.

\section{Effect of intact protein on indicators of calcium absorption}

Dietary casein, when compared to egg albumin augmented the level of ${ }^{45} \mathrm{Ca}$ in the soluble fraction of chyme of the small intestine (Lee et al. 1979). The rate of disappearance of ${ }^{45} \mathrm{Ca}$ from the intestinal ligated loop was highest in rats that had been fed on casein when compared to gluten, gelatine, dephosphorylated casein (Sato et al. 1983) whey protein or soy protein isolate (Nagasawa et al. 1991; Kitts et al. 1992). From the work of Sato et al. (1983) it became clear that the phosphorylated form of casein was a prerequisite, and therefore might be the cause for the enhancing effect of this protein on calcium solubility compared to other proteins.

\footnotetext{
* Corresponding author: K. E. Scholz-Ahrens, fax + 49431609 2472, email scholz-ahrens@bafm.de
} 


\section{Effect of isolated CPP on indicators of calcium absorption}

Mykkänen \& Wasserman (1980) observed a dose dependency of CPP. They demonstrated that the increase in duodenal ${ }^{47} \mathrm{Ca}$ absorption by CPP was more prominent in rachitic chicks than in control animals using an in situ experimental approach (ligated loop). Moreover, this effect was dose-dependent and was obvious only with a $1 \mathrm{mM}$, but not with a $25 \mathrm{~mm}$ solution of CPP. Such an effect was not observed if a tryptic hydrolysate of bovine serum albumin or different quantities of phosphate were injected. When different doses of CPP were incubated in vitro (everted sac method), higher amounts of calcium were transported out of the ileal lumen in a dose-dependent manner. Since the stimulatory effect on calcium absorption was not vitamin D-dependent, the authors concluded that CPP acted on the passive absorption pathway. The formation of soluble complexes of CPP with calcium, prevented precipitation of calcium phosphates and consequently raised the amount of soluble calcium (Mykkänen \& Wasserman, 1980). This assumption was confirmed in rats (Lee et al. 1979). The peptic hydrolysate of casein was twice more efficient than that of soy protein in raising the solubility of calcium in vitro (Sato et al. 1986).

Sato et al. (1986) isolated CPP from chyme and injected them together with a ${ }^{45} \mathrm{CaCl}_{2}$ solution into the ligated loop of rats. After $2 \mathrm{~h}$ of incubation the rate of disappearance of calcium was four times and the rate of calcium incorporation into bone three times higher than in the control group. In addition, dietary calcium was absorbed $15 \%$ more efficiently than endogenous calcium.

\section{Effect on mineral incorporation into bone}

Beside the effect on calcium absorption, dietary casein or CPP also stimulated calcium incorporation into bone. In the rat, instilled ${ }^{45} \mathrm{CaCl}_{2}$ disappeared sooner from the intestinal ligated loop and accumulated more efficiently in the femur when casein was fed compared to soy isolate (Sato et al. 1986). In rachitic chicks ${ }^{47} \mathrm{Ca}$ accumulation in the tibia was higher in the presence of CPP (Mykkänen \& Wasserman, 1980).

In young male rats fed on a diet containing $0.4 \%$ calcium and as little as $0.5 \%$ CPP for 3 weeks, ectopic bone induced in decalcified bone matrix implants was analysed (Matsui et al. 1994). In this model for bone mineralisation a higher content of calcium, lower values for concentration of tartrate-resistant acid phosphatase and less osteoclasts in implants were shown (Matsui et al. 1994). In another experiment, CPP increased calcification of cultured embryonic rat bone explants and calcium solubility in the culture medium (Gerber \& Jost, 1986). These findings suggest suppression of bone resorption and stimulation of bone mineralisation by CPP.

\section{CPP and cariogenicity}

Apart from a stimulatory effect of milk protein-derived phosphopeptides on mineral absorption and thereby on bone mineralisation, some dairy products, especially cheese, had an anticariogenic effect in animal and human caries models (Rosen et al. 1984; Harper et al. 1986; Silva et al. 1986, 1987). This effect was attributed to the phosphoprotein casein and to the calcium phosphate content of cheese (Silva et al. 1987). A direct positive effect of CPP on remineralisation of resected molar slab models was demonstrated by Reynolds (1997). CPP stabilised the calcium phosphate in solution and thus maintained a high concentration gradient of these minerals, a prerequisite for high rates of enamel remineralisation. In addition it was shown that CPP reduced adhesion of cariogenic microbes (Streptococcus mutans) (Schüpbach et al. 1996). Phosphopeptides are also present in human saliva (Minaguchi et al. 1988; Madapallimattam \& Bennick, 1990). Interestingly, they were able to inhibit hydroxyapatite formation, and could thus prevent undesired mineral formation on the tooth surface.

\section{Interaction between diet and $C P P$}

CPP increased calcium absorption from ligated ileal loops more markedly when added to a diet that contained soy protein isolate in place of casein (Kitts et al. 1992), indicating that dietary casein per se must have had a stimulating effect on calcium solubility and thus disappearance from the gut.

In the rat pup, not only calcium but also zinc absorption was improved after gastric intubation of Ca-containing CPP in the presence of phytate. No effect was found when a Nacontaining CPP preparation or casein or whey protein was added (Hansen et al. 1996). Further, the authors tested two types of infant formulas based on oat or soy. Zinc absorption was highest when the formula based on oat contained $\mathrm{Ca}-\mathrm{CPP}$ and was significantly improved when $\mathrm{Na}-\mathrm{CPP}$, casein or whey protein was added to the oat-based formula. When the formula was based on soy, only Na-CPP was effective (no values were given for the effect of CaCPP). Calcium absorption from oat-based diet was improved if Ca-CPP or casein was added. From the soybased diet only supplementation with Ca-CPP improved calcium absorption whereas Na-CPP reduced calcium absorption significantly. Zinc binding and uptake was higher after incubating Caco-2 cell culture with low concentrations of CPP, in contrast to high concentrations, which had an inhibitory effect (Hansen et al. 1996).

In summary, the published data on the effect of CPP/ casein on mineral solubility and absorption were inconsistent, which may partly be due to the diversity of experimental approaches. Nevertheless, CPP may have a potential to improve mineral balance of certain groups of the population that might be at risk for intakes below the recommended levels.

Meanwhile several potentially bioactive casein phosphopeptides have been described with different contents of phosphorylated serine residues. Gagnaire et al. (1996) were able to identify 14 different CPP after tryptic hydrolysis, ultracentrifugation, reversed-phase HPLC on-line electrospray ion source-mass spectrometry. Four CPP were isolated from $\alpha_{\mathrm{S}^{-}}$, two from $\alpha_{\mathrm{S}^{-}}$, and four from $\beta$-casein. Several different commercial protease preparations from bacterial, fungal, plant and animal origin can be used to yield CPP (McDonagh \& FitzGerald, 1998). 
The presence of a diversity of CPP after tryptic hydrolysis of casein, the observation that such CPP increased soluble calcium and calcium absorption from the ligated loop (Yuan \& Kitts, 1991), and exacerbated calcium incorporation into bone in vivo (Sato et al. 1986) pointed to an exciting potential of such phosphopeptides. The detection of CPP in the chyme of the small intestine of rats (Lee et al. 1980) or pigs (Meisel \& Frister, 1988) and in the faeces of rats (Kasai et al. 1992, 1995) following feeding of casein are compatible with bioactivity of CPP. It becomes obvious that nutrition studies are now required to establish physiological action in vivo and that only longterm studies can confirm improvement of not only calcium absorption but also calcium bioavailability. Therefore strengthening of bone under long-term conditions, i.e. adaptation by hormonal regulation, should be the parameter to indicate health benefits.

\section{Examples of established in vivo functions - long-term experiments}

\section{Effect of intact protein}

When rats were fed on casein compared to whey protein in the presence of phytate for 24 weeks, calcium retention was significantly higher (Scholz-Ahrens et al. 1993). This effect was obvious only in older adult rats, at the age of 29 weeks, after 24 weeks on diets. Stimulation of calcium retention was not observed when rats were young and rapidly growing, at the age of 11 weeks; after 6 weeks on diets or in younger adult rats (at the age of 20 weeks, after 16 weeks on diets). In older rats the capacity for calcium absorption and retention is lower than in younger animals (ScholzAhrens et al. 1996), probably because of reduced demands but also possibly due to decreased kidney and other organ function. It needs to be established whether aged subjects with presumably higher demands but reduced organ function, like postmenopausal women, would preferably benefit from CPP.

The minipig is well known as an animal model that is very close to the human, particularly with respect to nutrition physiology. Three experiments were performed in this species to study two milk proteins with different potential for CPP release and their effect on calcium and bone metabolism (Scholz-Ahrens et al. 1989, 1990a, b, c, 1991). In study one, 8-week-old weanling miniature piglets were fed a semisynthetic diet with $15 \%$ protein either as acid casein or whey protein concentrate for 12 weeks. During this time a doubling of weight was achieved. After 8 weeks calcium retention was significantly lower and plasma parathyroid hormone (PTH) tended strongly to be higher in minipigs fed casein compared to animals on whey protein concentrate (Table 1). After 12 weeks, the fraction of soluble calcium/total calcium in the chyme of small intestine was significantly lower whereas plasma concentration of calcium and PTH were significantly higher following casein compared to whey protein (Table 1, Scholz-Ahrens et al. 1989, 1990a). Body weight gain, calcium excretion with faeces or urine, apparent calcium absorption and plasma concentration of calcitonin were not different (Scholz-Ahrens et al. 1989). There was no
Table 1. Effect of dietary casein and whey protein concentrate on parameters of $\mathrm{Ca}$ metabolism in growing minipigs on $0.3 \%$ dietary $\mathrm{Ca}$

\begin{tabular}{|c|c|c|c|c|c|}
\hline & & \multicolumn{2}{|c|}{ Casein } & \multicolumn{2}{|c|}{ WPC } \\
\hline & & Mean & SEM & Mean & SEM \\
\hline \multicolumn{6}{|l|}{ After 8 weeks } \\
\hline Ca-retention & $g / 18 d$ & 11.54 & 0.02 & $13 \cdot 08^{*}$ & 0.10 \\
\hline \multicolumn{6}{|l|}{ Plasma } \\
\hline $\mathrm{Ca}$ & $\mathrm{mmol} / \mathrm{l}$ & 2.72 & 0.05 & 2.75 & 0.02 \\
\hline PTH & $\mathrm{nmol} / \mathrm{l}$ & 0.12 & 0.02 & 0.07 & 0.0 \\
\hline \multicolumn{6}{|l|}{ After 12 weeks } \\
\hline Soluble $\mathrm{Ca} /$ total Ca & & $2 \cdot 60$ & $0 \cdot 71$ & $6 \cdot 90^{*}$ & 0.71 \\
\hline \multicolumn{6}{|l|}{ Plasma } \\
\hline $\mathrm{Ca}$ & $\mathrm{mmol} / \mathrm{l}$ & $2 \cdot 60$ & 0.06 & $2 \cdot 39^{*}$ & 0.03 \\
\hline PTH & $\mathrm{nmol} / \mathrm{l}$ & 0.14 & 0.02 & $0.09^{*}$ & 0.01 \\
\hline
\end{tabular}

PTH, parathyroid hormone; WPC, whey protein concentrate.

${ }^{*} P<0.05 ; n=8$

$\dagger$ In the chyme of distal small intestine.

significant difference in one of the parameters measured in femora such as wet weight, ash content, calcium concentration, bone density (g hydroxylapatite $/ \mathrm{cm}^{3}$ ) measured by X-ray or bending moment between the dietary groups (Scholz-Ahrens et al. 1990b). The lower portion of soluble calcium in the small intestine at the end of the experiment after 12 weeks thus may not reflect less solubilisation. It may indicate an adaptation process towards faster absorption following casein. Nevertheless, the sum of single metabolic changes in pigs fed casein compared to whey protein concentrate had no persisting effect on bone mineralisation.

A second study was performed with identical study design except for dietary calcium content, which was $0 \cdot 8$ $\%$. Plasma ionic or total calcium, organic phosphate and alkaline phosphatase, soluble calcium in chyme of the distal small intestine were not different between the two diets (not shown). Higher plasma concentration of PTH after feeding a casein-containing diet was confirmed, at least in tendency $(P<0 \cdot 1$, Scholz-Ahrens et al. 1990c, Table 2). Concentrations of 25-(OH)-vitamin $\mathrm{D}_{3}$ were significantly higher in minipigs on diets containing casein compared to whey protein concentrate, but no effect of diet was seen on X-ray density of trabecular bone of femoral neck $(P=0 \cdot 5$, Table 2$)$. In that study (Scholz-Ahrens et al. 1990 c) calcium retention was not different between groups, with $1.09 \pm 0.08 \mathrm{~g} / \mathrm{d}$ when casein was fed, and $1.15 \pm$ $0.08 \mathrm{~g} / \mathrm{d}$ in animals on whey protein (mean \pm SEM).

Table 2. Effect of dietary casein and whey protein concentrate on parameters of $\mathrm{Ca}$ metabolism in growing minipigs on $0.8 \%$ dietary $\mathrm{Ca}$

\begin{tabular}{|c|c|c|c|c|c|}
\hline & & \multicolumn{2}{|c|}{ Casein } & \multicolumn{2}{|c|}{ WPC } \\
\hline & & Mean & $\overline{\text { SEM }}$ & Mean & SEM \\
\hline \multicolumn{6}{|l|}{ After 12 weeks } \\
\hline \multicolumn{6}{|l|}{ Plasma } \\
\hline $\begin{array}{l}\text { PTH } \\
25(\mathrm{OH}) \mathrm{D}_{3}\end{array}$ & $\mathrm{nmol} / \mathrm{l}$ & 0.18 & 0.03 & $0.11^{*}$ & $0 \cdot\left(\begin{array}{c}0 \\
25\end{array}\right.$ \\
\hline $\begin{array}{l}25(\mathrm{OH}) \mathrm{D}_{3} \\
\text { X-ray bone density }\end{array}$ & $\mathrm{nmol} / \mathrm{l}$ & 342 & 21 & $262 \dagger$ & $\begin{array}{l}22 \\
21\end{array}$ \\
\hline X-ray bone density & $\mathrm{mg} / \mathrm{cm}^{3}$ & 297 & 13 & 312 & 21 \\
\hline
\end{tabular}

PTH parathyroid hormone; WPC, whey protein concentrate.

* $P<0.1$

$\dagger P<0.05, n=8$. 
Table 3. Effect of dietary casein and whey protein concentrate on parameters of $\mathrm{Ca}$ metabolism in growing minipigs on diets containing $0.8 \%$ dietary $\mathrm{Ca}$ and lacking vitamin $\mathrm{D}$

\begin{tabular}{|c|c|c|c|c|c|}
\hline & & \multicolumn{2}{|c|}{ Casein } & \multicolumn{2}{|c|}{ WPC } \\
\hline & & Mean & SEM & Mean & SEM \\
\hline \multicolumn{6}{|l|}{ After 8 weeks } \\
\hline \multicolumn{6}{|l|}{ Plasma } \\
\hline $\begin{array}{c}25(\mathrm{OH}) \mathrm{D}_{3} \\
\text { After } 12 \text { weeks }\end{array}$ & $\mathrm{nmol} / \mathrm{l}$ & 39.5 & $3 \cdot 1$ & $30 \cdot 7^{*}$ & $2 \cdot 6$ \\
\hline \multicolumn{6}{|l|}{ Plasma } \\
\hline $1,25(\mathrm{OH})_{2} \mathrm{D}_{3}$ & $\mathrm{pmol} / \mathrm{l}$ & $82 \cdot 3$ & $16 \cdot 3$ & $129 \cdot 2^{*}$ & $14 \cdot 8$ \\
\hline Femur Ca & $\mathrm{mg} / \mathrm{g}$ & 188 & $2 \cdot 37$ & $179^{*}$ & $2 \cdot 70$ \\
\hline
\end{tabular}

WPC, whey protein concentrate.

${ }^{*} P<0.05 ; n=19$.

The third study was similar to study 2 except that the animals were vitamin D-depleted (Scholz-Ahrens et al. 1991). After 8 weeks plasma concentrations of calcidiol were significantly higher following casein compared to whey protein concentrate (Table 3). After 12 weeks significantly lower plasma concentrations of calcitriol $\left(1,25(\mathrm{OH}) \mathrm{D}_{3}\right)$ were observed in the minipigs on casein. There was no difference in calcium balance or calcium content in trabecular bone of lumbar vertebra after 12 weeks. However, calcium concentration in the femur was slightly but significantly higher when casein was fed (Table 3 ). The higher calcidiol concentration indicates an increased capacity for calcium absorption. Thus, the increased femur calcification following casein-derived CPP might be mediated via a rise in plasma calcidiol concentration as the initial step. The improved femur mineralisation is compatible with reduced plasma calcitriol concentrations if lower calcitriol indicated a reduced bone turnover. The way in which different dietary proteins could have triggered this effect could not be explained. The vitamin $\mathrm{D}$ content of each protein preparation was not different (both below detectable level).

The authors concluded from the experiments in minipigs (Scholz-Ahrens et al. 1989; 1990a, b, c, 1991) that the effect of casein-derived CPP on calcium balance and bone performance was small in minipigs, an animal model that is closer to humans than the rat. Changes in calcium metabolism by CPP were detectable only at lower dietary calcium or if vitamin D supply was insufficient. The latter effect was in agreement with that reported by Mykkänen \& Wasserman (1980) in vitamin D-deficient chicken. Therefore, CPP might be of minor relevance under physiological conditions, when counterbalance by hormonal regulation occurs. Nevertheless, a possible effect of isolated CPP or special CPP preparations could not be excluded especially if an optimum ratio of CPP and dietary calcium are used (Saito et al. 1998).

\section{Effect of CPP preparations}

Two experiments have been carried out in rats that investigated the effect of the concentrated CPP preparation, kindly provided by Sopharga, France, which was given for 7 weeks (Kopra et al. 1992). The CPP was characterised by Brulé et al. (1982) in more detail in a United States patent.
The diets contained $0.8 \%$ calcium, $0.6 \%$ phosphorus and $1.8 \%$ CPP. In vitamin D-replete (experiment 1) or in vitamin D-deficient rats (experiment 2 ) there was no effect of different milk proteins (casein $v$. whey protein) or of CPP, when added to the whey containing diet, on calcium balance, dry weight, ash, calcium, or phosphorus contents of femora (Kopra et al. 1992). The results are in accordance with those reported by Yuan \& Kitts (1991) after feeding of CPP to rats for 10 weeks. In spite of higher ${ }^{45} \mathrm{Ca}$ absorption from the ligated loop, calcium balance was not improved.

In contrast, Tsuchita et al. (1995) observed in male growing rats significantly higher serum osteocalcin and reduced urinary cAMP when calcium-containing phosphopeptides (Ca-CPP) were included into a diet compared to a control group based on egg albumin. Considering this finding, they suggested Ca-CPP stimulated bone formation. Femur and humerus weights were significantly higher. However, this was not due to a better mineralisation but to other, organic components. Calcium, magnesium and phosphorus contents in humerus and calcium and magnesium content in femur were not different. Phosphorus content was higher but only in femur. Bone mineral density (BMD) was higher at three out of nine sites analysed at the excised femur and two out of nine at the humerus. This beneficial effect on bone density was only achieved by $\mathrm{Ca}$ $\mathrm{CPP}$, and not when a preparation free of calcium (Ca-free $\mathrm{CPP})$ was given. In the $\mathrm{Ca}$-free $\mathrm{CPP}$ diet calcium was included as $\mathrm{CaCO}_{3}$. It remains questionable whether $\mathrm{Ca}$ CPP promoted bone formation by way of the $9 \%$, but nonsignificantly higher phosphorus retention, as reported by Tsuchita et al. (1995). It appears more probable that the increase in plasma alkaline phosphatase, serum osteocalcin, and renal tubular reabsorption rate, and the lower urinary cAMP following $\mathrm{Ca}-\mathrm{CPP}$ reflected metabolic responses to the difference in phosphorus absorption which was $16 \%$ lower (although non-significant) in the diet containing $\mathrm{Ca}$ CPP.

Tsuchita et al. (1993a) did not observe changes in calcium balance by CPP in ovariectomised (OVX) rats. Results are also in accordance with those in aged OVX rats, that did not develop higher femoral weight, ash, calcium or phosphorus, bone mineral content (BMC) or BMD of lumbar vertebrae (Tsuchita et al. 1996). The BMD of three out of nine segments of femur was higher after feeding of Ca-CPP. Loss of BMD in vivo was not prevented significantly before week 16 . No positive effect on bone performance was observed with a CPP preparation free of calcium but enriched with $\mathrm{CaCO}_{3}$ (Ca-free CPP). On the contrary, animals on diets containing Ca-free CPP lost almost $20 \%$ of their body weight (Tsuchita et al. 1996). The authors did not report the feed consumption. Therefore, it remains speculative as to whether a lower feed intake, lower biological value of the protein, part of that special CPP preparation, or other ingredients were responsible for the negative effect on body weight and presumably BMD in vivo. Other studies in animal models did not show a significant beneficial effect of CPP on calcium absorption or bone metabolism in vivo (Brommage et al. 1991; Pointillart \& Guéguen, 1989).

It was reported that not only metabolism of calcium but also of other minerals and other aspects of mineral status 
may be influenced by CPP. In young iron-deficient rats CPP-bound iron affected some parameters of iron status and metabolism positively, such as mean cell volume, haemoglobin and haematocrit, and some negatively, such as urine iron (Aït-Oukhatar et al. 1997). Other parameters like iron absorption or red blood cells were not affected. The authors concluded that binding iron to CPP seemed to improve its bioavailability, a finding recently confirmed by Pérès et al. (1999), and hasten the cure of iron deficiency in the young rat (Ait-Oukhatar et al. 1997). Another micronutrient (zinc) was found to bind to casein-derived CPP and to casein as long as it was not dephosphorylated (Harzer \& Kauer, 1982).

\section{Phosphopeptides other than CPP}

Some authors suggested that not only the casein fraction is a source of bioactive components with regard to bone metabolism, but also whey (Tsuchita et al. 1993b). They compared two different whey mineral complexes (WMC I and WMC II) differing in sodium, potassium, chloride and protein content or $\mathrm{CaCO}_{3}$ in a feeding trial in growing rats. There was no difference in calcium and phosphorus retention, urinary hydroxyproline excretion (a parameter of bone resorption) between different calcium sources either at $0.3 \%$ or $0.6 \%$ dietary calcium. WMC II induced only a small and temporary decrease of urinary cAMP (a parameter of PTH function), higher activities of alkaline phosphatase, calcium concentration in femur, and bone density in humerus when dietary calcium content was high. The authors speculated that this effect could be mediated by some small nitrogenous compounds that deserve further investigation or by trace lipids occurring in WMC after processing. In particular, the lipid fraction of WMC II was rich in oestradiol and calcitriol and raised the plasma concentration of these steroids in OVX rats. Furthermore, calcium absorption, femur calcium and humerus bone density were higher (Tsuchita \& Kuwata, 1995).

\section{Potential or established health benefits}

Most of the findings in the literature that dealt with the mineral absorption-stimulating effect of CPP were based on in vitro, in situ, cell culture or single meal studies. The majority of studies were done in rats. A summary of those results provided considerable evidence for a potential effect of casein-derived phosphopeptides to improve mineral absorption. This potential was not limited to calcium but was also valid for zinc and iron, and possibly other elements that had not been investigated until now.

Only a few investigations have been performed as longterm experiments. However, only a long-term experimental approach allows extrapolation from beneficial action of CPP to physiological significance in terms of human health. In vitro studies and short-term in situ or single meal experiments are excellent and important approaches for studying the influence of dose, type of CPP preparation, basal dietary calcium (habitual calcium), protein source, meal effect and interaction with other nutrients or diet components or to compare physiological reactions in different animal species. Regarding bone health, however, such studies are of limited relevance as long as no improvement on bone performance, such as bone mineralisation, density, or stability, was shown. It became obvious from the long-term experiments in animal models, that adaptation via hormonal regulation may lead to a zero effect on bone in spite of transient improvements in some parameters. Controlled long-term experiments in humans are difficult to perform. Hansen et al. (1997) investigated in single meal experiments the effect of CPP on calcium and zinc absorption from infant foods given to twenty two young adult individuals. When whole body retention of radioisotopes was measured, calcium and zinc absorptions were improved from rice-based cereal, whereas no effect was seen from whole-grain cereal. In osteoporotic women with low basal absorptive capacity CPP incorporation improved calcium absorption in a single meal experiment (Heaney et al. 1994).

\section{Conclusion}

It is obvious that long-term studies in humans are needed if conclusions are to be drawn from the evidence of specific effects of phosphopeptides seen in vitro, in situ and in single meal experiments. Bone density or other parameters of bone quality should be monitored if claims on bone health are to be made. There is a need for further studies in order to confirm beneficial effects on human health in general or for certain groups of population.

\section{References}

Aït-Oukhatar N, Bouhallab S, Bureau F, Arhan P, Maubois J-L, Drosdowsky MA \& Bouglé DL (1997) Bioavailability of caseinophosphopeptide bound iron in the young rat. Journal of Nutritional Biochemistry 8, 190-194.

Brommage R, Juillerat MA \& Jost R (1991) Influence of casein phosphopeptides and lactulose on intestinal calcium absorption in adult female rats. Lait 71, 173-180.

Brulé G, Roger L, Fauquant J \& Piot M (1982) Phosphopeptides from casein-based material. United States Patent 4,361,587.

Gagnaire V, Pierre A, Molle D \& Leonil J (1996) Phosphopeptides interacting with colloidal calcium phosphate isolated by tryptic hydrolysis of bovine casein micelles. Journal of Dairy Research 63, 405-422.

Gerber HW \& Jost R (1986) Casein phosphopeptides: their effect on calcification of in vitro cultured embryonic rat bone. Calcified Tissue International 38, 350-357.

Hansen M, Sandström B \& Lönnerdal B (1996) The effect of casein phosphopeptides on zinc and calcium absorption from high phytate infant diets assessed in rat pups and caco-2 cells. Pediatric Research 40, 547-552.

Hansen M, Sandström B, Jensen M \& Sørensen SS (1997) Casein phosphopeptides improve zinc and calcium absorption from rice-based but not from whole-grain infant cereal. Journal of Pediatric Gastroenterology and Nutrition 24, 56-62.

Harper D, Osborn JC, Hefferren JJ \& Clayton R (1986) Cariostatic evaluation of cheeses with diverse physical and compositional characteristics. Caries Research 20, 123-130.

Harzer G \& Kauer H (1982) Binding of zinc to casein. American Journal of Clinical Nutrition 35, 981-987.

Heaney RP, Saito Y \& Orimo H (1994) Effect of caseinphosphopeptide on absorbability of co-ingested calcium in normal 
postmenopausal women. Journal of Bone and Mineral Metabolism 12, 77-81.

Kasai T, Honda T \& Kiriyama S (1992) Caseinphosphopeptides (CPP) in faeces of rats fed casein diet. Bioscience Biotechnology and Biochemistry 56, 1150-1151.

Kasai T, Iwasaki R, Tanaka M \& Kiriyama S (1995) Caseinphosphopeptides (CPP) in faeces and contents in digestive tract of rats fed casein and CPP preparations. Bioscience Biotechnology and Biochemistry 59, 26-30.

Kitts DD, Yuan YV, Nagasawa T \& Moriyama Y (1992) Effect of casein, casein phosphopeptides and calcium intake on ileal ${ }^{45} \mathrm{Ca}$ disappearance and temporal systolic blood pressure in spontaneously hypertensive rats. British Journal of Nutrition 68, 765-781.

Kopra N, Scholz-Ahrens KE \& Barth CA (1992) Effect of casein phosphopeptides on utilisation of calcium in vitamin D-replete and vitamin D-deficient rats. Milchwissenschaft 47, 488-493.

Lee YS, Noguchi T \& Naito H (1979) An enhanced intestinal absorption of calcium in the rat directly attributed to dietary casein. Agricultural and Biological Chemistry 43, 2009-2011.

Lee YS, Noguchi T \& Naito H (1980) Phosphopeptides and soluble calcium in the small intestine of rats given a casein diet. British Journal of Nutrition 43, 457-467.

Lee YS, Noguchi T \& Naito H (1983) Intestinal absorption of calcium in rats given diets containing casein or amino acid mixture: the role of casein phosphopeptides. British Journal of Nutrition 49, 67-76.

Li Y, Tomé D \& Desjeux JF (1989) Indirect effect of casein phosphopeptides on calcium absorption in rat ileum in vitro. Reproduction Nutrition and Development 29, 227-233.

Madapallimattam G \& Bennick A (1990) Phosphopeptides derived from human salivary, acidic proline-rich proteins biological activities and concentration in saliva. Biochemical Journal 270, 297-304.

Matsui T, Yano H, Awano T, Harumoto T \& Saito Y (1994) The influences of casein phosphopeptides on metabolism of ectopic bone induced by decalcified bone matrix implantation in rats. Journal of Nutritional Science and Vitaminology 40, 137-145.

McDonagh D \& FitzGerald RJ (1998) Production of caseinophosphopeptides (CPPs) from sodium caseinate using a range of commercial protease preparations. International Dairy Journal 8, 39-45.

Meisel H \& Frister H (1988) Chemical characterisation of a caseinophosphopeptide isolated from in vivo digests of a casein diet. Biological Chemistry Hoppe-Seyler 369, 1275-1279.

Mellander O (1947) On chemical and nutritional differences between casein from human and from cow's milk. Upsala Läkareförenings Förhandlinger 52, 107-128.

Mellander O (1950) The physiological importance of the casein phosphopeptide calcium salts. II Peroral calcium dosage of infants. Acta Societatis Medicorum Uppsaliensis 55, 247-255.

Mellander O (1963) Phosphopeptides: chemical properties and their possible role in the intestinal absorption of metals. In The Transfer of Calcium and Strontium Across Biological Membranes, pp. 265-276 [RH Wasserman, editor]. New York: Academic Press.

Minaguchi K, Madapallimattam G \& Bennick A (1988) The presence and origin of phosphopeptides in human saliva. Biochemical Journal 250, 171-177.

Mykkänen HM \& Wasserman RH (1980) Enhanced absorption of calcium by casein phosphopeptides in rachitic and normal chicks. Journal of Nutrition 110, 2141-2148.

Nagasawa T, Yuan YV \& Kitts DD (1991) Casein phosphopeptides enhance paracellular calcium absorption but do not alter temporal blood pressure in normotensive rats. Nutrition Research 11, 819-830.

Naito H, Kawakami A \& Imamura T (1972) In vivo formation of phosphopeptide with calcium-binding property in the small intestinal tract of the rat fed on casein. Agricultural and Biological Chemistry 36, 409-415.

Naito H \& Suzuki H (1974) Further evidence for the formation in vivo of phosphopeptide in the intestinal lumen from dietary Bcasein. Agricultural and Biological Chemistry 38, 1543-1545.

Pérès H-M, Bouhallab S, Bureau F, Neuville D, Maubois J-L, Devroede G, Arhan P \& Bouglé D (1999) Mechanisms of absorption of caseinophosphopeptide bound iron. Journal of Nutritional Biochemistry 10, 215-222.

Pointillart A \& Guéguen L (1989) Absence d'effet de l'incorporation d'un phosphopeptide du lait sur l'utilisation du calcium et du phosphore chez le jeune porc. Reproduction Nutrition Development 29, 477-486.

Reeves RE \& Latour NG (1958) Calcium phosphate sequestering phosphopeptide from casein. Science 128, 472.

Reynolds C (1997) Remineralization of enamel subsurface lesions by casein phosphopeptide-stabilized calcium phosphate solutions. Journal of Dental Research 76, 1587-1595.

Rosen S, Min DB, Harper DS, Harper WJ, Beck EX \& Beck FM (1984) Effect of cheese, with and without sucrose, on dental caries and recovery of Streptococcus mutans in rats. Journal of Dental Research 63, 894-896.

Saito Y, Lee YS \& Kimura S (1998) Minimum effective dose of casein phosphopeptides (CPP) for enhancement of calcium absorption in growing rats. International Journal of Vitaminology and Nutrition Research 68, 335-340.

Sato R, Noguchi T \& Naito H (1983) The necessity for the phosphate portion of casein molecules to enhance $\mathrm{Ca}$ absorption from the small intestine. Agricultural and Biological Chemistry 47, 2415-2417.

Sato R, Noguchi T \& Naito H (1986) Casein phosphopeptide (CPP) enhances calcium absorption from the ligated segment of rat small intestine. Journal of Nutritional Science and Vitaminology 32, 67-76.

Scholz-Ahrens KE, Ackermann J, de Vrese M \& Barth CA (1993) Effect of casein on the antagonistic action of dietary phytate on calcium absorption in rats. In Bioavailability '93, Nutritional, Chemical and Food Progressing implications of Nutrient Availability, pp. 215-218 [U Schlemmer, editor]. Karlsruhe: Berichte der BFE.

Scholz-Ahrens KE, Hess J \& Barth CA (1996) Knochenmineralisation und Bruchstabilität in Abhängigkeit von Calciumzufuhr, Alter und Skelettbereich bei der Ratte. Zeitschrift für Ernährungswissenschaft 35, 91-92.

Scholz-Ahrens KE, Kopra N \& Barth CA (1990b) Effect of casein phosphopeptides on utilization of calcium in minipigs and vitamin-D-deficient rats. Zeitschrift für Ernährungswissenschaft 29, 295-298.

Scholz-Ahrens KE, Kopra N, de Vrese M \& Barth CA (1989) Influence of casein and whey protein concentrate on calcium balance, bone density and plasma calcitonin and parathyroid hormone in Göttingen minipigs. In Proceedings of the 2nd Symposium on Preventive and Therapeutic Use of Calcium, Vitamin D, and Other Calciotropic Drugs, Prague, pp. 108 [JE Purkyně, editor]. Prague: Tiskařské Zárody.

Scholz-Ahrens KE, Kopra N, de Vrese M \& Barth CA (1990a) Einfluß verschiedener Milchproteine auf den Calciumhaushalt bei bedarfsgerechter und stark reduzierter Calciumzufuhr. Ernährungsumschau 37, 170.

Scholz-Ahrens KE, Kopra N, de Vrese M \& Barth CA (1990c) Einfluß von Casein und Molkenprotein auf die Calciumbilanz, Knochenmineralisation und Plasma-Konzentration von Parathormon und Vitamin-D-Metaboliten beim Miniaturschwein. Journal of Animal Physiology and Animal Nutrition 64, 19.

Scholz-Ahrens KE, de Vrese M \& Barth CA (1991) Influence of casein-derived phosphopeptides on the bioavailability of 
calcium in vitamin D-deficient miniature pigs. In Vitamin D, Gene Regulation, Structure-Function Analysis and Clinical Application, pp. 724-725 [AW Norman, R Bouillon and M Thomasset, editors]. Berlin: W de Gruyter.

Schüpach P, Neeser JR, Golliard M, Rouvet M \& Guggenheim B (1996) Incorporation of caseinoglycomacropeptide and caseino phosphopeptide into the salivary pellicle inhibits adherence of mutans streptococci. Journal of Dental Research 75, 17791788.

Silva MF, de A, Burgess RC \& Sandham HJ (1987) Effects of cheese extract and its fractions on enamel demineralization in vitro and in vivo in humans. Journal of Dental Research 66, $1527-1531$.

Silva MF, de A, Jenkins GN, Burgess RC \& Sandham HJ (1986) Effects of cheese on experimental caries in humans. Caries Research 20, 263-269.

Tsuchita H, Goto T, Shimizu T, Yonehara Y \& Kuwata T (1996) Dietary casein phosphopeptides prevent bone loss in aged ovariectomized rats. Journal of Nutrition 126, 86-93.
Tsuchita H, Goto T, Yonehara Y \& Kuwata T (1995) Calcium and phosphorus availability from casein phosphopeptides in male growing rats. Nutrition Research 15, 1657-1667.

Tsuchita H \& Kuwata T (1995) Trace lipid from whey-mineral complex enhances calcium availability in young ovariectomized rats. British Journal of Nutrition 73, 299-309.

Tsuchita H, Sekiguchi I \& Kuwata T (1993b) Comparison of the effects of whey mineral complexes on bone metabolism in male growing rats. Journal of Nutritional Science and Vitaminology 39, 473-487.

Tsuchita H, Sekiguchi I, Kuwata T, Igarashi C \& Ezawa I (1993a) The effect of casein phosphopeptides on calcium utilization in young ovariectomized rats. Zeitschrift für Ernährungswissenschaft 32, 121-130.

Yuan YV \& Kitts DD (1991) Confirmation of calcium absorption and femoral utilization in spontaneously hypertensive rats fed casein phosphopeptide supplemented diets. Nutrition Research 11, 1257-1272. 